\title{
BIOMASS PRODUCTION OF WHEAT GROWN UNDER DIFFERENT WATERLOGGING CONDITIONS AND THE IMPACT ON SEED VIGOR
}

\author{
PRODUÇÃO DE BIOMASSA DE TRIGO CULTIVADA SOB DIFERENTES \\ CONDIÇÕES DE ALAGAMENTO DO SOLO E IMPACTO NO VIGOR DE \\ SEMENTES
}

\section{Tiago PEDÓ ${ }^{3}$, Cristian TROYJACK ${ }^{1}$; João Roberto PIMENTEL ${ }^{1}$; Felipe KOCH ${ }^{1}$; Emanuela Garbin MARTINAZZO²; Tiago Zanatta AUMONDE; Francisco Amaral VILELLA}

1. Doutorando (a) em C\&T de Sementes, Bolsista CNPq, UFPel, Pelotas, RS, Brasil; 2. Professora, Doutora, Instituto de Biologia, Universidade Federal do Rio Grande - FURG; 3. Professor, Doutor, Faculdade de Agronomia Eliseu Maciel, Departamento de Fitotecnia, Programa de Pós-Graduação em C\&T de Sementes - UFPel; 4. Professor, Doutor, Faculdade de Agronomia Eliseu Maciel, Departamento de Fitotecnia, Programa de Pós-Graduação em C\&T de Sementes - UFPel, Bolsista de Produtividade em Pesquisa do $\mathrm{CNPq}-\mathrm{PQ} 2$

\begin{abstract}
The aims of this study are to provide a comparative analysis of the growth and the expression of seed vigor from wheat plants subjected to periods of waterlogging during the development period. The treatments consisted of different combinations of soil waterlogging: $\mathrm{T} 1=$ no waterlogging; $\mathrm{T} 2=$ two waterlogging periods, at stages $\mathrm{Z} 25$ and Z45; and T3 = three waterlogging periods, at stages Z25, Z45 and Z75. Plants were collected at regular intervals after emergence until the end of the cycle: 14, 28, 42, 56, 70, 84, 98 and 112 days after emergence (DAE). Dry mass and leaf area of samples were determined. From the primary data, the analysis of growth was applied, and the total dry mass, dry matter production, relative growth and net assimilation rates, leaf area, leaf area ratio, leaf mass ratio and specific leaf area were calculated. Seedling emergence, seedling emergence rate index and dry mass of seedling shoots and roots were also evaluated. Wheat plants grown in conditions of field capacity demonstrated better performance compared to those subjected to three periods of soil waterlogging, with higher total dry mass and net assimilation rates. Seedling emergence and seedling emergence rate index did not differ between treatments. However, soil waterlogging for two or three periods resulted in a reduction in the dry matter of roots and shoots of wheat seedlings. The growth of wheat plants was found to be negatively affected by soil waterlogging. The expression of seed vigor from plants not exposed to soil waterlogging was similar to that of plant seeds subjected to soil waterlogging, although seedling growth was affected negatively by waterlogging conditions.
\end{abstract}

KEYWORDS: Triticum aestivum L. Abiotic stress. Growth. Hypoxia. Emergence speed index.

\section{INTRODUCTION}

Wheat is a plant from the Poaceae family which is widely cultivated during the winter in South Brazil (CARVALHO et al., 2016). In the 2016/2017 harvest, wheat cultivated area was $2,118,400$ hectares, with production of $6,726,800$ tons of grain and productivity of $3175 \mathrm{~kg} \mathrm{ha}^{-1}$, with the states of Paraná and Rio Grande do Sul accounting for $91 \%$ of production (CONAB, 2017).

Rio Grande do Sul has several different agro-ecosystems, between them lowland, which is nearly $20 \%$ of the southern territory, approximately 5.4 million hectares (MARCHEZAN et al., 2002). Currently, these production areas are used to cultivate irrigated rice and extensive cutting farming on routinely sub utilization. Therefore, improved use of these areas, involving a diverse range of crops is important for increased food production, for which there is a growing need.
Lowland soils of the planosol class present densification on the B horizon and deep percolation of negligible water (BAMBERG et al., 2009). The soil exhibits reduced porosity and a high incidence of waterlogging during rainy periods, and is associated with high retention of water during periods of dry weather (PAULETTO et al., 2004). These physical characteristics result in inadequate drainage, leading to conditions of hypoxia and to a fermentative process, and consequently limit the growth and development of various rain-fed crops which may be reflected in losses in yield and seed quality. For this reason, due to the fact that wheat (Triticum aestivum L.) is economically relevant and has a high degree of adaptability (BIUDES et al., 2009), can be an alternative to be used in areas of lowland soil maximizing its use.

Growth analysis consists of an accessible and precise method used to evaluate the plant growth for describing changes in plant production depending on time, which is not possible with a 
simple performance register, being fundamental for the performance or for the growth characterization and plant development (URCHEI et al., 2000). This technique allows inferring in a simple and low cost the contribution of different physiological processes on plant behavior and consists in the first step to interpret and analyze primary production, an important tool on the behavior study of plants under different environment and management conditions (AUMONDE et al., 2013).

In this context, this study aimed to provide a comparative analysis of growth and expression of seed vigor in wheat plants subjected to periods of waterlogging during the development cycle.

\section{MATERIAL AND METHODS}

The study was carried out in the Rio Grande do Sul state, Brazil (location $31^{\circ} 52^{\prime} \mathrm{S}$ and $52^{\circ} 21^{\prime}$ $\mathrm{W})$. The experiment was conducted in a greenhouse (chapel model), positioned in a north-south orientation, coated with polycarbonate and equipped with temperature and relative humidity controls. Maximum and minimum temperature data and solar radiation data (with a correction factor of $36.67 \%$ for the greenhouse interior) were obtained from the climatological bulletin of the Pelotas Agroclimatological Station for the year 2014, site 100 meters of the experiment and are shown in Figure 1.

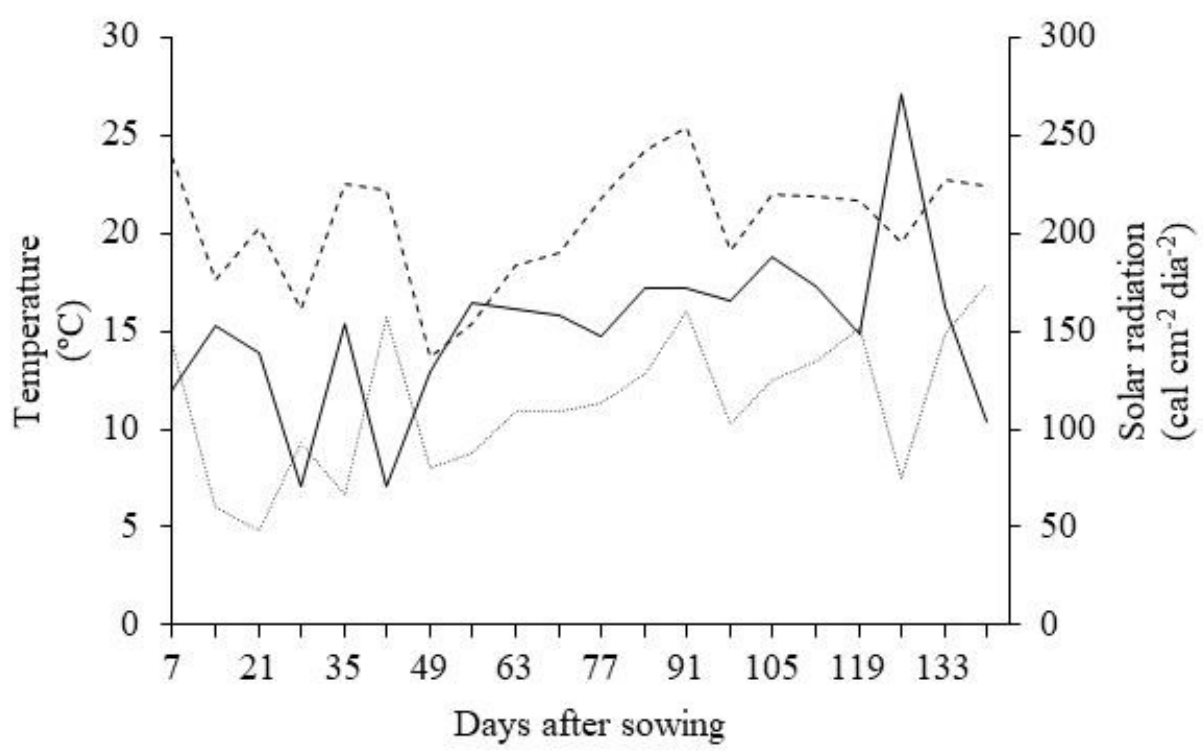

Figure 1. Solar radiation (-), maximum temperature $(-\cdot)$ and minimum temperature $(\cdots \cdots)$ during the period of the experiment.

Seeds from the wheat cultivar Fundacep Bravo were sown in black polyethylene pots, with a capacity of 14 liters and filled with topsoil, on $25^{\text {th }}$ May 2012. The substrate soil was obtained from the A1 horizon of a solodic haplic eutrophic Planosol, belonging to the mapping unit of Pelotas. Chemical and physical properties of the soil were as follows: $\mathrm{pH}\left(\mathrm{H}_{2} \mathrm{O}\right)$ 5.4; $\mathrm{P} 15.5 \mathrm{mg} \mathrm{dm}^{-3} ; \mathrm{K}_{54} \mathrm{mg} \mathrm{dm}^{-3} ; \mathrm{Ca}$ $2.8 \mathrm{cmolc} \mathrm{dm}^{-3}$; Mg $0.5 \mathrm{cmolc} \mathrm{dm}^{-3}$; Al 0.4 cmolc $\mathrm{dm}^{-3}$; Fe $1400 \mathrm{mg} \mathrm{dm}^{-3}$; Cu $0.3 \mathrm{mg} \mathrm{dm}^{-3}$; Zn $0.9 \mathrm{mg}$ $\mathrm{dm}^{-3}$; Mn $27.0 \mathrm{mg} \mathrm{dm}^{-3}$; CTC $6.0 \mathrm{cmolc} \mathrm{dm}^{-3}$; base saturation $54 \%$; organic matter $1.4 \%$; clay $15 \%$. Previously the soil was corrected according to soil analysis and based on the Manual of Fertilization (CQFS RS/SC, 2004). Four wheat plants (Triticum aestivum $\mathrm{L}$.) were kept in each plot.

A completely randomized experimental design was used, with six replicates. The treatments consisted of a combination of three soil waterlogging conditions. $\mathrm{T} 1=$ no soil waterlogging, with soil being maintained at close to field capacity throughout the cycle. $\mathrm{T} 2=$ soil subjected to two periods of waterlogging during the plant cycle, the first period occurring in the vegetative phase, during tillering at the Z25 stage (45 days after emergence), and the second period of waterlogging occurring during the Z45 stage (75 days after emergence). T3 $=$ soil submitted to three periods of waterlogging during the plant cycle, the first two occurring as for $\mathrm{T} 2$ and the third period occurring during seed filling at stage Z75 (116 days after emergence) (ZADOCKS et al., 1974). Each period of soil waterlogging lasted for three days. Plants were collected at nine time-points: $14,28,42,56,70,84$, 98 and 112 days after emergence (DAE). 
Polyethylene pots containing the topsoil had holes drilled through the bottom to facilitate drainage of excess water and to ensure maintenance of a state of field capacity in the soil. Field capacity was determined using the voltage table methodology (EMBRAPA, 1997). Following the determination of field capacity, the volume of water required to achieve waterlogged conditions for a three-day period was established. Maintenance of a $20 \mathrm{~mm}$ layer of water on the soil surface was achieved by fitting a second, non-perforated, black polyethylene pot under each perforated pot, with the aim of preventing gas exchange and soil aeration. Draining of soaked soil was achieved by removing nonperforated pots and allowing soil to return to the field capacity level. Non-perforated pots were not used in treatment $\mathrm{T} 1$.

Evaluations were performed on plant material collected at 14-day intervals after emergence for the entire developmental phase of the wheat plants. At each collection time, plants were clipped close to the ground and manually separated into component organs (roots, leaves, stems and cobs), seing collected all the plant root system and washed in sieves. Each plant fraction was then separately placed in a brown paper envelope. Dry matter was obtained by transferring material to a forced ventilation oven, set at a temperature of $65 \pm$ $2{ }^{\circ} \mathrm{C}$, for 72 hours until constant mass was achieved (NAKAGAWA, 1994).

Leaf area $\left(\mathrm{L}_{\mathrm{a}}\right)$ was determined using a Licor model LI-3100 area meter. Primary data of total accumulated dry matter $\left(\mathrm{W}_{\mathrm{t}}\right)$ were adjusted using the simple logistic equation: $\mathrm{W}_{\mathrm{t}}=\mathrm{W}_{\mathrm{m}} /\left(1+\mathrm{Ae}^{-\mathrm{Bt}}\right)$, where $" \mathrm{~W}_{\mathrm{m}}$ " was the asymptotic estimate of maximum growth, "A" and "B" adjustment constants, "e" the natural neperian base logarithm and " $\mathrm{t}$ " the time in days after emergence (RICHARDS, 1969). Instantaneous values of the rate of dry matter production $\left(\mathrm{C}_{\mathrm{t}}\right)$ were determined by fitting derived equations for the total dry matter $\left(\mathrm{W}_{\mathrm{t}}\right)$ in relation to time (RADFORD, 1967). Instantaneous relative growth rates $\left(R_{w}\right)$ were determined using the following equation: $R_{w}=$ $1 / \mathrm{W}_{\mathrm{t}} \cdot \mathrm{d}_{\mathrm{w}} / \mathrm{d}_{\mathrm{t}}$, seing: $\mathrm{d}_{\mathrm{w}}$ derived from dry matter and $\mathrm{d}_{\mathrm{t}}$ derived as a function of time. Instantaneous values of net assimilation rate $\left(\mathrm{E}_{\mathrm{a}}\right)$, leaf area ratio $\left(\mathrm{F}_{\mathrm{a}}\right)$, leaf mass ratio $\left(\mathrm{F}_{\mathrm{w}}\right)$ and specific leaf area $\left(\mathrm{S}_{\mathrm{a}}\right)$ were estimated using the equations $\mathrm{E}_{\mathrm{a}}=1 / \mathrm{A}_{\mathrm{f}} \cdot \mathrm{d}_{\mathrm{w}} / \mathrm{d}_{\mathrm{t}}, \mathrm{F}_{\mathrm{a}}=$ $\mathrm{A}_{\mathrm{f}} / \mathrm{W}_{\mathrm{t}}, \mathrm{F}_{\mathrm{w}}=\mathrm{W}_{\mathrm{f}} / \mathrm{W}_{\mathrm{t}}$ and $\mathrm{S}_{\mathrm{a}}=\mathrm{A}_{\mathrm{f}} / \mathrm{W}_{\mathrm{f}}$, respectively, according to Radford (1967), all adjustments of the equations performed according to the recommendations of the Radford (1967) and Richards (1969).
Seeds were harvested manually on $10^{\text {th }}$ October 2014, when they had a water content of $18 \%$. Seeds were then dried to a water content of $13 \%$ and stored in a cold-room with controlled temperature and relative humidity. To determine the physiological quality of the seeds, several evaluations were carried out. Seedling emergence (SE) was conducted in a greenhouse, using four subsamples of 50 seeds per treatment, arranged to germinate in trays of black polyethylene which contained the above characterized soil, maintained at field capacity conditions according to methodology described. Emergence speed index (ESI) was determined from the daily count of the number of seedlings emerged from the substrate, as proposed by Maguire (1962). Seedling leaf area $\left(\mathrm{L}_{\mathrm{a}} \mathrm{S}\right)$ was evaluated at 21 days after sowing; four sub-samples of 10 seedlings were collected per treatment and leaf area was determined using a Licor model LI-3100 area meter; results were expressed in $\mathrm{cm}^{2}$. Dry mass of seedlings $\left(\mathrm{W}_{\mathrm{ap}} / \mathrm{W}_{\mathrm{r}}\right)$ was evaluated at 21 days after sowing. Four subsamples of 10 seedlings were collected per treatment and separated into aerial parts and roots. Each fraction was placed separately in a brown paper envelope and subjected to drying in a forced air circulation oven (temperature $65 \pm 2{ }^{\circ} \mathrm{C}$ ) until constant mass was achieved (NAKAGAWA, 1994). Dry mass was determined on a precision scale and results were expressed in milligrams.

Primary data for total dry matter, leaf area, dry matter of leaves, roots, stems and ears were subjected to analysis of variance, and data on growth analysis using a simple logistic equation (RADFORD, 1967; PEDÓ et al., 2013a). Since growth data are of the quantitative type, their trend was evaluated through growth curves (BARREIRO et al., 2006). Data relating to seedling emergence, emergence speed index of seedlings, leaf area of seedling and dry matter of seedling collected were subjected to analysis of variance and, when the $\mathrm{F}$ values were significant, treatment means were compared using Tukey's test $(p<0.05)$.

\section{RESULTS}

The analysis of variance for primary growth data is shown in Table 1. From the analysis of the mean squares for the data on leaf area and dry weight of organs, it was observed that there was a high degree of significance $(1 \%)$ between waterlogged conditions and harvest times. 
Table 1. Summary of analysis of variance with mean squares of leaf area $\left(\mathrm{A}_{\mathrm{f}}\right)$, dry matter of leaves $\left(\mathrm{W}_{\mathrm{f}}\right)$, stems $\left(\mathrm{W}_{\mathrm{c}}\right)$, roots $\left(\mathrm{W}_{\mathrm{r}}\right)$ and cobs $\left(\mathrm{W}_{\mathrm{e}}\right)$.

\begin{tabular}{lcccccc}
\hline Fv & GL & \multicolumn{5}{c}{ Mean squares } \\
\cline { 3 - 7 } & & \multicolumn{1}{c}{$\mathrm{A}_{\mathrm{f}}$} & $\mathrm{W}_{\mathrm{f}}$ & $\mathrm{W}_{\mathrm{c}}$ & $\mathrm{W}_{\mathrm{r}}$ & $\mathrm{W}_{\mathrm{e}}$ \\
\hline Conditions (CON) & 2 & $3897.9^{* *}$ & $0,069^{\mathrm{ns}}$ & $0.714^{\mathrm{ns}}$ & $3.825^{\mathrm{ns}}$ & $1.486^{\mathrm{ns}}$ \\
Seasons (SEA) & 8 & $105360.3^{* *}$ & $17.10^{* *}$ & $52.15^{* *}$ & $116.8^{* *}$ & $115.2^{* *}$ \\
CON x SEA & 16 & $9610.1^{* *}$ & $0.625^{* *}$ & $1.176^{* *}$ & $12.26^{* *}$ & $1.564^{* *}$ \\
Residue & 52 & 523.8 & 0.116 & 0.292 & 0.941 & 0.270 \\
\hline Average & & 163.6 & 2.3 & 2.7 & 3.6 & 2.4 \\
CV(\%) & 13.99 & 14.98 & 20.08 & 26.96 & 21.33
\end{tabular}

Level of significance $\left(p=* * 0.01\right.$ and ${ }^{\mathrm{ns}}$ not significant).

Total dry matter $\left(\mathrm{W}_{\mathrm{t}}\right)$ of wheat plants grown in soil at field capacity and in waterlogged soil adjusted to the logistic tendency with a high determination coefficient (Figure 2A). Regardless of the period of waterlogging used, there was a slow initial plant growth until 42 DAE. This was followed by a quick growth period until $126 \mathrm{DAE}$, when plants subjected to three waterlogging periods presented a worse performance for carbon allocation $\left(546.63 \mathrm{~g} \mathrm{~m}^{-2}\right)$ compared to those grown in soil at field capacity $\left(665.73 \mathrm{~g} \mathrm{~m}^{-2}\right)$ or with two waterlogging periods $\left(656.58 \mathrm{~g} \mathrm{~m}^{-2}\right)$, the latter two treatments producing similar values.

In wheat plants, $C_{t}$ values were affected by the different waterlogging periods (Figure 2B). Plants grown in soil maintained at field capacity or subjected to two waterlogging periods reached the highest $\mathrm{C}_{\mathrm{t}}$ value at $98 \mathrm{DAE}$, while plants subjected to three waterlogging periods reached the highest $\mathrm{C}_{\mathrm{t}}$ value at 84 DAE. In addition, plants grown in waterlogged soil demonstrated lower rates of dry matter production.

Maximal $R_{w}$ values occurred in plants at 14 DAE and were similar for plants grown in soil at field capacity and those subjected to soil waterlogging (Figure 2C). There was a tendency for systematic decrease in $R_{w}$ throughout the development cycle with all treatments. When plants maintained in soil under field capacity reached higher values when compared to those under two and three soil waterlogging. From the 70 DAE, inversion occurred in the $\mathrm{Rw}$ values between plants submitted to two or three periods of waterlogging, where plants submitted to three soil waterlogging obtained values of $R_{w}$ higher than those with two soil waterlogging.

The leaf area $\left(\mathrm{L}_{\mathrm{a}}\right)$ adjusted to the cubical trend with a high determination coefficient in plants kept at soil capacity and subjected to soil waterlogging $\left(R^{2} \geq 0.96\right)$ (Figure $\left.2 \mathrm{D}\right)$. Plants grown in soil at field capacity achieved the largest leaf area during the growth cycle at $70 \mathrm{DAE}$, followed by a subsequent decrease. This was similar to plants grown in waterlogged soils, although $\mathrm{L}_{\mathrm{a}}$ values for these plants were superior to the former plants.

The net assimilation rate $\left(\mathrm{E}_{\mathrm{a}}\right)$ showed two peaks throughout wheat plant development in field capacity soil and also in plants grown in waterlogged conditions, following the expected ontogenic pattern (Figure 2E). The highest peak of $\mathrm{E}_{\mathrm{a}}$ occurred at $14 \mathrm{DAE}$ with all treatments. Values of $E_{a}$ showed a tendency for strong growth from 84 DAE, with a highest peak at 112 DAE with all the treatments, the higher values occurring in plants grown in soil at field capacity compared to those grown in waterlogged conditions.

Regardless of the treatment employed, $F_{a}$ values were highest at the beginning of the development cycle at 28 DAE with all treatments, with a subsequent decrease until the end of the cultivar cycle (Figure 2F). Plants grown in soil at field capacity and those subjected to three waterlogging periods presented similar leaf area ratio, however, lower when compared to those under the effect of two waterlogging periods.

In plants of all treatments, $F_{w}$ reached maximum values at $28 \mathrm{DAE}$, with a subsequent tendency to decrease throughout the development of the plants (Figure 2G). Plants grown with three periods of waterlogging reached a higher leaf mass ratio in comparison to those grown at field capacity or those subjected to two waterlogging periods. 

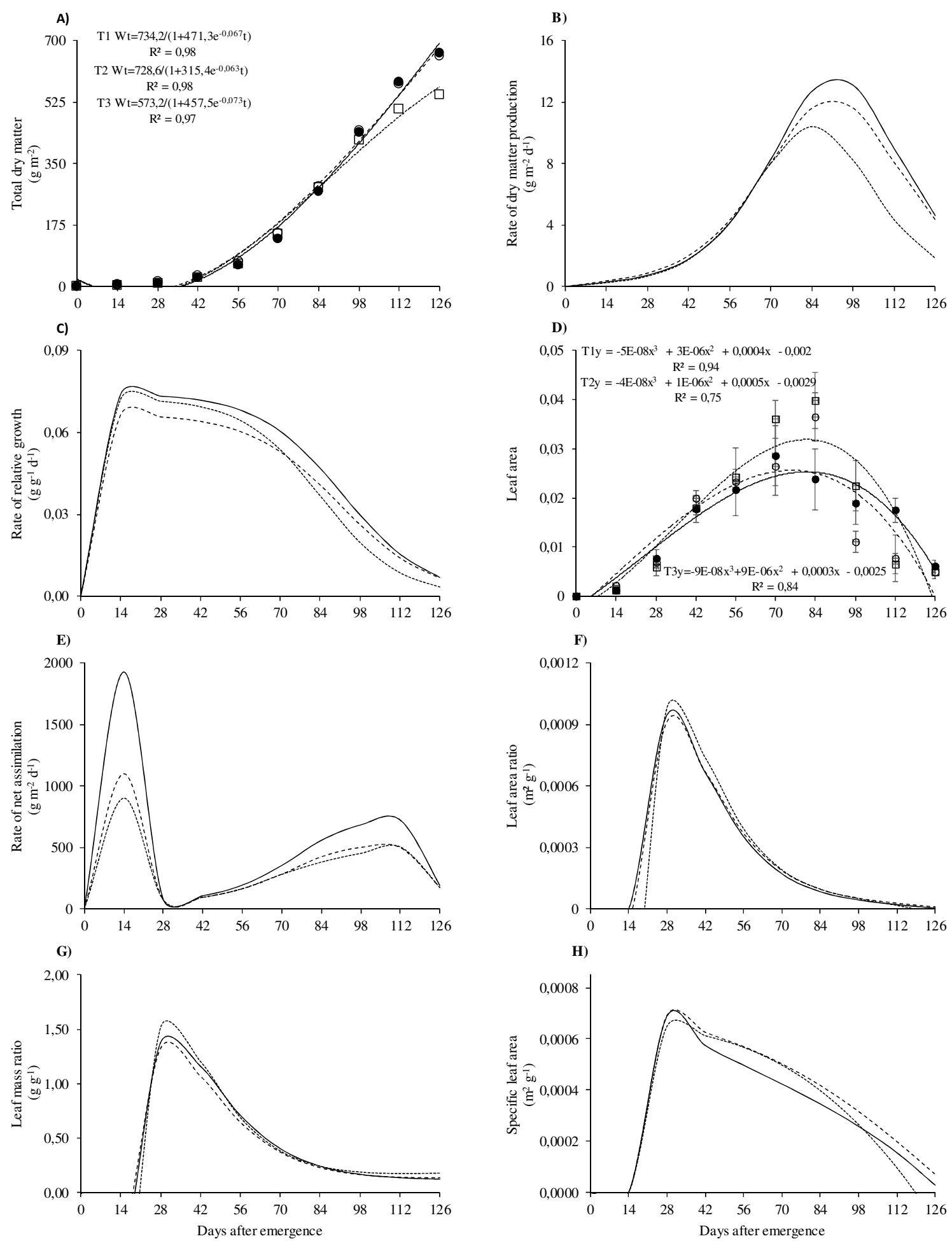

Figure 2. Total dry matter (A), rate of dry matter production (B), relative growth (C), leaf area (D), net assimilation $(\mathrm{E})$, leaf area ratio $(\mathrm{F})$, leaf mass $(\mathrm{G})$ and specific leaf area $(\mathrm{H})$ of wheat plants $(T$. aestivum L.) subjected to waterlogging. Data: soil at field capacity $(-)$, two $(--)$ and three waterlogging periods (......).

The specific leaf area $\left(\mathrm{S}_{\mathrm{a}}\right)$ reached its maximum in the beginning of the development cycle in wheat plants, both in those grown in soil at field capacity and in those subjected to waterlogging
(Figure 2H). Plants grown in field capacity soil and those subjected to two waterlogging periods had similar specific leaf area values that were higher in comparison to those subjected to three waterlogging 
periods. However, when comparing plants grown at field capacity to the plants grown with two waterlogging periods, the latter showed higher values of $S_{a}$ in the period between 42 DAE and 84 DAE, while plants grown with three waterlogging periods showed higher values of $S_{a}$ from 42 DAE until the end of the cultivar cycle. Therefore, the periods of waterlogging appeared to result in wider and less thick leaves in wheat plants.

Both the emergence and the emergence speed rate in substrate did not differ between seedlings originating from plants grown in soil at field capacity and those grown with periods of soil waterlogging (Table 2). There was a quantitative alteration among the attributes of growth of seedlings originating from plants grown at field capacity and those grown in waterlogged conditions, where the plants grown in soil at field capacity and those subjected to two waterlogging periods had seedlings with wider leaf areas in comparison to those subjected to three waterlogging periods. However, plants grown in soil at field capacity produced seedlings with higher root and shoots dry matter in comparison to plants grown under the effect of waterlogging.

Table 2. Seedling emergence (SE), emergence speed index (ESI), leaf area of seedling $\left(\mathrm{L}_{\mathrm{a}} \mathrm{S}\right)$, dry matter of the root $\left(\mathrm{W}_{\mathrm{t}}\right)$ and shoot $\left(\mathrm{W}_{\mathrm{ap}}\right)$ of wheat seedlings subjected to waterlogging during the growth and seed filling.

\begin{tabular}{|c|c|c|c|c|c|}
\hline Treatments & $\begin{array}{c}\text { SE } \\
(\%)\end{array}$ & ESI & $\begin{array}{c}\mathbf{L}_{\mathbf{a}} \mathbf{S} \\
\left(\mathrm{cm}^{2}\right)\end{array}$ & $\begin{array}{c}\mathbf{W}_{\mathbf{r}} \\
(\mathrm{mg})\end{array}$ & $\begin{array}{c}\mathbf{W}_{\text {ap }} \\
(\mathrm{mg})\end{array}$ \\
\hline Absence of waterlogging (*FC) & $86 \mathrm{a}^{1}$ & $42.1 \mathrm{a}$ & $11.1 \mathrm{a}$ & $19.9 \mathrm{a}$ & $45.4 \mathrm{a}$ \\
\hline Two waterlogging periods & $84 a$ & $40.9 \mathrm{a}$ & $10.5 \mathrm{a}$ & $11.8 b$ & $38.6 b$ \\
\hline Three waterlogging periods & $85 \mathrm{a}$ & $40.5 \mathrm{a}$ & $8.9 b$ & $11.9 \mathrm{~b}$ & $36.4 b$ \\
\hline$* * \mathrm{CV}(\%)$ & 3.95 & 5.05 & 7.23 & 6.85 & 5.27 \\
\hline
\end{tabular}

\section{DISCUSSION}

Low initial growth in plants is common and can be explained by low water and nutrient absorption, small leaf area and by the low respiration and net assimilation during the initial period of development (MONTEITH, 1969). Therefore, growth, in terms of volume rise, dry matter, linear dimensions or structural units, is a matter of structural carbon storage (AUMONDE et al., 2011). On the other hand, plants under the effect of soil soaking, present a reduced synthesis in the allocation of proteins, with a negative impact in enzymatic activity (ZABALZA et al., 2008; CHRISTIANSON et al., 2010). Still, it promotes a rise in the production and accumulation of reactive species of oxygen due to the environmental stimulation to which the plants are exposed. These molecules can oxidize lipids, proteins and nucleic acids (AZEVEDO NETO et al., 2006) and can be a limitation to the plant survival.

In this study, exposure of plants to two periods of waterlogging resulted in negative quantitative changes in the dry matter quantity produced per time, while plants subjected to three waterlogging periods presented a time-quantitative reduction in $\mathrm{C}_{\mathrm{t}}$ in comparison to those plants grown in soil at field capacity. The rise in dry matter production rate can be related, among some limits, to the increase in leaf area and the amount of photoassimilates synthesized and partitioned between the different plant organs (LOPES \& MAESTRI, 1973). While the quantitative or time-quantitative dry matter production rate may be related to the stressor effect proportionated by hypoxia caused by the waterlogging under different physiological and chemical processes related to the growth and plant development. Waterlogging alters the physicalchemical characteristics of the soil, preventing gas exchange between roots and soil pores and limiting oxygen availability (MIELKE et al., 2003), reducing metabolic activity and translocation of assimilates (DREW, 1997) and diminishing dry mass accumulation during periods of stress condition.

It is possible to infer that the soil waterlogging influenced on the capacity of dry matter accumulation in relation to that pre-existent. However, the high values of $R_{w}$ at the beginning of plant ontogeny is related to the fact that a larger proportion of the leaf area is comprised of young leaves with high photosynthetic capacity and growth rate. On the other hand, the decrease in $R_{w}$ as the plant grows is, in part, a result of the graduate increase in non-photosynthetic tissues during plant 
development, due to the high respiratory activity, variation in weather conditions (LOPES et al., 1986) and to the self-shading that can be evidenced by the increase in leaf area (Figure 2D).

Waterlogging of soil affected the leaf area index compared to plants grown in soil at field capacity. Therefore, it is possible to verify that occurrence of waterlogged conditions during the vegetative and reproductive phase of wheat plant growth promotes the increase of the soil area occupied by leaves. Lack of oxygen in waterlogged soil induces a quick reduction in the photosynthetic rate, due to stomatal closure (PARENT et al., 2008). According to observations in this study, there was a quantitative delay of $\mathrm{E}_{\mathrm{a}}$ in plants exposed to conditions of waterlogging, fact that maintains a relation to the minors $\mathrm{C}_{\mathrm{t}}$ and $\mathrm{W}_{\mathrm{t}}$ (Figures. 2A-B). In this context, there is evidence of reduced efficiency in the production of net assimilated throughout the development cycle of the wheat plants when they were subjected to waterlogging, it can be inferred that in plants with higher $\mathrm{E}_{\mathrm{a}}$ and not exposed to soil waterlogging, the difference between photosynthesis and respiration was higher in comparison to plants under the effect of such abiotic stress (MARENCO \& LOPES, 2007).

Plants grown in soil at field capacity presented a second peak of $E_{a}$ which was greater than plants subjected to the two or three periods of waterlogging. This can be explained by $E_{a}$ being determined, not only by photosynthetic rate, but also by the leaf area dimension, duration of vegetative period, leaf distribution in the canopy, leaf angle, translocation and assimilate partitioning (AUMONDE et al., 2011). Through the beginning of the development cycle, the higher assimilation rate in wheat plants is related to a higher investment of assimilates in creation of the photosynthetic apparatus, with the aim of increasing the leaf area available to receive light in the autotrophic phase of the plant. Meanwhile, the higher rise of $E_{a}$ aims to increase the biosynthesis of the carbon compounds for the allocation in seeds, strong and final drain (PEDÓ et al., 2013b).

From the results of $\mathrm{F}_{\mathrm{a}}$ it can be inferred that plants grown in soil at field capacity presented a smaller leaf area available for photosynthesis. In addition, in the beginning of plant development, the marked increase in $\mathrm{F}_{\mathrm{a}}$ is due to the fact that a large proportion of the assimilates are destined to leaf formation in order to ensure greater uptake of solar radiation (URCHEI et al., 2000), according to that shown by the leaf area index (Fig. 2D). Still, the strong tendency for decrease throughout the specie cycle, is partially due to the fact that there is a gradual increase in the non-assimilatory tissues and the reproductive organ formation, where the latter are build up from a preferential metabolic sink (AUMONDE et al., 2011; PEDÓ et al., 2013a), competing with plant structures for the assimilates produced, inducing the leaf senescence (BRIGHENTI et al., 1993).

Plants they reached a higher carbon allocation and other leaf compounds, in comparison to plants under the other treatments (PEDÓ et al., 2013a). In the beginning of the plant development, leaves have a high capacity for mobilizing assimilates (AUMONDE et al., 2011) and, when moving forward to the plant ontogeny with the reproductive structures formation, there is a change of the preferential drain when the leaves stop acting as a strong drain and export the carbon allocated to the seeds or fruits (PEDÓ et al., 2013a).

To manufacture the metabolic activities, there is a need to relocate the reservation carbohydrates since these are essential for the tolerance in waterlogging periods (PARENT et al., 2008). Therefore, plants under the effect of two waterlogging periods had a point reduction in the percentage of dry matter allocated in roots can be due to the increase of the greater allocation of the dry matter on the wheat ears aiming a higher carbon allocation in the reproductive structures.

Soil waterlogging did not alter the seed vigor expression, regardless of the number of waterlogging periods, measured by attributes related to the germination process. Vigor is constituted by a set of physiological, biochemical and cytological attributes that can be modified in the field during seed development, against certain environmental conditions. Peske et al., (2012) and Marcos Filho (2015) report that seed vigor is related to proper cultivation and management development of the plant and seed.

Even though the germination process of wheat seeds was not influenced negatively by the soil waterlogging, there was an alteration in the quantity of assimilates allocated in the seedling, which is related to the reorganization of the cellular membrane system, hydrolase, translocation and carbon accumulation in the seedling (PESKE et al., 2012). It is important to mention that the smaller leaf area of seedlings originating from plants subjected to three soil waterlogging periods results in a smaller uptake of solar radiation area that can influence negatively the photochemical stage of photosynthesis and the competitive performance of the plant (PEDÓ et al., 2013b).

Therefore, in general, wheat plants grown in soil at field capacity presented a better performance 
in comparison to those subjected to the effect of three waterlogging periods, producing higher values for $\mathrm{W}_{\mathrm{t}}$ and $\mathrm{E}_{\mathrm{a}}$. Seed vigor expression, indicated by the speed of emergence, did not differ between plants from the different treatment groups. However, soil waterlogging for two or three periods resulted in reduction in the dry matter of roots and shoots of wheat seedlings.

Thus, wheat plant growth is altered negatively by the soil waterlogging because the stressor effect is higher and the abiotic stress period is superior. And besides, the expression of seed vigor of wheat plants originated from waterlogging is similar to the ones of seeds of plants under the effect of soil waterlogging, even though the growth on the seedlings is affected negatively by the abiotic stress mentioned before.

\section{ACKNOWLEDGEMENTS} scholarship.

The authors thank CAPES for granting the
RESUMO: O objetivo deste estudo é fornecer uma análise comparativa do crescimento e da expressão do vigor das sementes das plantas de trigo submetidas a períodos de alagamento do solo durante o ciclo de desenvolvimento. Os tratamentos consistiram em diferentes combinações de alagamento do solo: $\mathrm{T} 1$ = sem alagamento do solo; T2 = dois períodos de alagamento do solo, nos estágios Z25 e Z45; e T3 = três períodos de alagamento do solo, nos estádios Z25, Z45 e Z75. As plantas foram coletadas em intervalos regulares após a emergência até o final do ciclo: 14, 28, 42, 56, 70, 84, 98 e 112 dias após a emergência (DAE). Foi determinada a massa seca e a área foliar das amostras. A partir dos dados primários, foi aplicada a análise do crescimento, calculando-se a massa seca total, a taxa de produção de matéria seca, o crescimento relativo e a taxa de assimilatória líquida, área foliar, razão de área foliar, razão de massa foliar e área foliar específica. A emergência de plântulas, o índice de emergência das plântulas e a massa seca de parte aérea e raízes de plântulas foram avaliados. As plantas de trigo cultivadas em condições de capacidade de campo demonstraram melhor desempenho em comparação com aqueles submetidos a três períodos de alagamento do solo, com maior massa seca total e taxa de assimilatória líquida. O índice de emergência e o índice de emergência de plântulas não diferiram entre os tratamentos. No entanto, o alagamento do solo durante dois ou três períodos resultou em uma redução na matéria seca de raízes e de parte aérea de plântulas de trigo. O crescimento das plantas de trigo foi afetado negativamente pelo alagamento do solo. A expressão do vigor das sementes de plantas não expostas ao alagamento do solo foi semelhante à das sementes de plantas submetidas ao alagamento do solo, embora o crescimento das plântulas tenha sido afetado negativamente pelas condições de inundação.

PALAVRAS-CHAVE: Triticum aestivum L. Estresses abióticos. Crescimento. Hipoxia. Índice de velocidade de emergência.

\section{REFERENCES}

AUMONDE, T. Z.; LOPES, N. F.; MORAES, D. M.; PEIL, R. M. N.; PEDÓ, T. Growth of Smile ${ }^{\circledR}$ hybrid mini watermelon grafted and ungrafted. Interciencia, v. 36, n. 1, p. 677-681. 2011.

http://en.ahau.findplus.cn/?h=articles\&db=edselc\&an=edselc.2-52.0-80053009325

AUMONDE, T. Z.; PEDÓ, T.; MARTINAZZO, E. G.; MORAES, D. M.; VILLELA, F. A.; LOPES, N. F. Growth analysis and partitioning of assimilates in mary-nightshade plants submitted to shading levels. Planta Daninha, v. 31, n. 1, p. 99-108. 2013. http://www.scielo.br/pdf/pd/v31n1/11.pdf

AZEVEDO NETO, A. D.; PRISCO, J. T.; ENEAS FILHO, J.; ABREU, C. E. B.; GOMES FILHO, E. Effect of salt stress on antioxidative enzymes and lipid peroxidation in leaves and roots of salt-tolerant and salt-sensitive maize genotypes. Environmental and Experimental Botany, v. 56, n. 1, p. 87-94. 2006.

https://www.researchgate.net/publication/223321881

BARREIRO, A. P.; ZUCARELI, A.; ONO, E. O.; RODRIGUES, J.D. Growth analysis of basil plants submitted to plant growth regulators. Bragantia, v. 65, n. 4, p. 563-567, 2006. http://dx.doi.org/10.1590/S0006-87052006000400005. 
BAMBERG, A. L.; PAUlETO, E. A.; GOMES, A. S. G.; TIMM, L. C.; PINTO, L. F. S.; LIMA, A. C. R.; SILVA, T.R. Bulk density of an alfisol under cultivation systems in a long-term experiment evaluated with gamma ray computed tomography. Revista Brasileira de Ciência do Solo, v. 33, n. 1, p. 1079-1086, 2009. https://www.researchgate.net/publication/262462360_Bulk_density_of_an_alfisol_under_cultivation_systems_i n_a_long-term_experiment_evaluated_with_Gamma_Ray_computed_tomography

BIUDES, G. B.; CAMARGO, C. E. O.; FERREIRA FILHO, A. W. P.; PETTINELLI JÚNIOR, A.; FOLTRAN, D. E.; CASTRO, J. L.; AZEVEDO, FILHO, J. Á. Adaptability and stability of wheat dihaploid lines. Bragantia, v. 68, n. 1, p. 63-74, 2009. http://dx.doi.org/10.1590/S0006-87052009000100008

BRIGHENTI, A. M.; SILVA, J. F.; LOPES, N. F.; CARDOSO, A. A.; FERREIRA, L. R. Growth and partition of assimilates of wormwood. Revista Brasileira de Fisiologia Vegetal, v. 5, n. 1, p. 41-45, 1993.

CARVALHO, I. R; NARDINO, M.; DEMARI, G.; SZARESKI, V. J. ; AUMONDE, T. Z. ; PEDO, T. ; MONTEIRO, M. A. ; PELEGRIN, A. J. ; OLIVOTO, T.; FERRARI, M. ; MEIRA, D. ; SOUZA, V. Q. Biometry and genetic breeding of dual-purpose wheat. International Journal of Current Research, v. 8, n. 7, p. 3439-34545, 2016

CQFS RS/SC. 2004. Manual of fertilization and liming for the State of Rio Grande do Sul and Santa Catarina. Porto Alegre, SBCS/Núcleo Regional Sul, UFRGS.

CHRISTIANSON, J. A.; LLEWELLYN, D. J.; DENNIS, E. S.; WILSON, I. W. Global gene expression responses to waterlogging in roots and leaves of cotton (Gossypium hirsutum L.). Plant Cell Physiology. v. 51. n. 1. p. 21-37. 2010. https://www.ncbi.nlm.nih.gov/pubmed/19923201

CONAB - Companhia Nacional de Abastecimento. Acompanhamento da safra Brasileira: grãos, sétimo levantamento abril 2017. Companhia Nacional de Abastecimento, Brasília: Conab 2017. http://www.conab.gov.br/olalaCMS/uploads/arquivos/16 0407103911 boletim grãos abril 2017.pdf. Accessed Abr. 06, 2018.

DREW, M. Oxygen deficiency and root metabolism: injury and acclimation under hypoxia and anoxia. Annual Review Plant Physiology and Plant Molecular Biology. v. 48, n. 1, p. 223-250, 1997.

http://www.annualreviews.org/doi/10.1146/annurev.arplant.48.1.223

EMBRAPA. Manual methods of soil analysis. Rio de Janeiro: Embrapa/CNPS. 1997.

LOPES, N. F.; MAESTRI, M. Growth analysis and solar energy conversion in populations of maize (Zea mays L.) Revista Ceres, v. 20, n. 1, p. 189-201. 1973.

LOPES, N. F.; OLIVA, M. A.; CARDOSO, M.; GOMES, M. M. S.; SOUZA, V. F. Growth and conversion of solar energy into Phaseolus vulgares L. subjected to three and radiant flux densities and two water regimes. Revista Ceres, v. 33, n. 1, p. 142-164. 1986.

MAGUIRE, J. D. Speed of germination-aid in selection and evaluation for seedling emergence and vigor. Crop Science, Madison, v. 2, n. 1, 176-177. 1962.

MARCHEZAN, E.; VIZZOTTO, V. R.; ROCHA, M. G.; MOOJEN, E. L.; SILVA, J. H. S. Animal weight gain in a systemized lowland area sown with winter pasture species and different fertilization levels. Ciência Rural, v. 32, n. 2. p. 303-308. 2002. http://dx.doi.org/10.1590/S0103-84782002000200020

MARCOS FILHO, J. Physiology of seeds of cultivated plants. 2. ed., Londrina: ABRATES, 2015, 660 p.

MARENCO, R. A.; LOPES, N. F. Plant physiology: photosynthesis, respiration, water relations and mineral nutrition. Viçosa: UFV 2007. 468 p. 
MIELKE, M. S.; ALMEIDA, A, F.; GOMES, F. P.; AGUILAR, M. A. G.; MANGABEIRA, P. A. O. Leaf gas exchange, chlorophyll fluorescence and growth responses of Genipa americana seedlings to soil flooding.

Environmental and Experimental Botany, v. 50. n. 1, p. 221-231. 2003. DOI: 10.1016/S00988472(03)00036-4

MONTEITH, J. L. Light interception and radiative exchange in crop stands. In: EASTIN, J. D.; HASKINS, F. A.; SUlLIVAN, C. T.; VAN BAVEL, C. H. M. (eds.) Physiological aspects of crop yield. Madison: American society of Agronomy, p.89-111, 1969.

NAKAGAWA, J. Testes de vigor baseados na avaliação das plântulas. In: VIEIRA, R.D.; CARVALHO, N.M. Testes de vigor em sementes. Jaboticabal: FUNEP, 1994. p.49-85.

PAULETTO, E. A.; GOMES, A. S.; PINTO, L. F. S. Física de solos de várzea cultivados com arroz irrigado. In:__GOMES, A.S.; MAGALHÃES, J. R., A. M. Arroz irrigado no sul do Brasil. Brasília, Embrapa Informação Tecnológica, 2004. p.119-142.

PARENT, C,; CAPELLI, N.; BERGER, A.; CRÈVECOEUR, M.; DAT, J.F. An overview of plant responses to soil waterlogging. Plant Stress, v. 2, n. 1, p. 20-27. 2008.

http://www.fertitech.com/site/DefaultSite/filesystem/documents/An\%20Overview\%20of\%20Plant\%20Respons es\%20to\%20Soil\%20Waterlogging.pdf

PEDÓ, T.; AUMONDE, T. Z.; LOPES, N. F.; VILLELA, F. A.; MAUCH, C. R. Comparative analysis of growth between genotypes of pepper grown in greenhouse. Bioscience Journal, v. 29, n. 1. p. 125-131. $2013 \mathrm{a}$. http://www.seer.ufu.br/index.php/biosciencejournal/article/view/13889/11976

PEDÓ, T. MARTINAZZO, E. G.; AUMONDE, T. Z.; VILLELA, F. A. Physiological principles in seed production. In: Schuch LOB, Vieira JFV, Rufino CA, Abreu Júnior JS, Seeds: Production, quality and technological innovation. Pelotas, Editora e Gráfica Universitária. 2013b.

PESKE, S. T.; VILLELA, F. A.; MENEGHELLO, G. E. Sementes: fundamentos científicos e tecnológicos. 3 ed. Pelotas: Editora Universitária-UFPel, 2012. 573 p.

RADFORD, P. J. Growth analysis formulae: their use and abuse. Crop Science, v.7. p. 171-175. 1967.

RICHARDS, F. J. The quantitative analysis of growth. In: treatise. New York: Academic press. 1969. p.3-7. STEWWARD, F.C. Plant Physiology. A

URCHEI, M. A.; RODRIGUES, J. D.; STONE, L. F. Growth analysis of two bean cultivars under irrigation in no tillage and the conventional tillage. Pesquisa Agropecuária Brasileira, v. 35, n. 3. p. 497-506. 2000. http://dx.doi.org/10.1590/S0100-204X2000000300004

ZABALZA, A.; DONGEN, J. T. V.; FROEHLICH, A.; OLIVER, S. N.; FAIX, B.; GUPTA, K. J.; SCHMÄLZLIN, E.; IGAL, M.; ORCARAY, L.; ROYUELA, M; GEIGENBERGER, P. Regulation of respiration and fermentation to control the plant internal oxygen concentration. Plant Physiology, v. 149, p. 1087-1098, 2008. www.plantphysiol.org/cgi/doi/10.1104/pp.108.129288

ZADOKS, J. C.; CHANG, T. T.; KONZAK, C. F. A decimal code for the growth stages of cereals. Weed Research, v. 14, p. 415-421, 1974. 